\title{
Use of BCG as an immunostimulant after resection of carcinoma of the lung: a two-year assessment of a trial of 500 patients $^{* \dagger}$
}

\author{
F RONALD EDWARDS
}

From the Cardiothoracic Surgical Unit, Broadgreen Hospital, Liverpool L14 3LB, UK

ABSTRACT BCG (Glaxo) $\left(0.5 \mathrm{ml}=5 \times 10^{6}\right.$ organisms) was given subdermally to 250 patients ten days after resection of a lung carcinoma to stimulate the immune system. Increased activity of lymphocytes and macrophages could possibly result in the destruction of small extrapulmonary tumour deposits that were previously unidentified. The two-year survival of this group of patients was compared with 250 controls not receiving BCG after operation. A comparative analysis of the sex, histological types, and lymph node involvement in relation to the survivals occurring in these two groups showed that the administration of BCG by the method described produced a numerically greater survival rate, which was particularly noticeable in the women. None of these figures, however, is statistically significant. It would be unwise to draw any final conclusion until a five-year survey has been completed.

That some immunological control over the growth of cancer cells in the body might be obtained by increasing the number and activity of lymphocytes and macrophages has been shown from experiments in animals undertaken by many investigators. Various agents-zymosan (Bradner et al 1958), phytohaemagglutinin (Oppenheim et al, (1965), Corynebacterium parvum (Halpern et al, 1966), oestrogen (Biozzi et al, 1957) Bacille Calmette-Guèrin (BCG) (Old et al, 1959), and others-have been shown to be active stimulators for this purpose.

Clearly whatever agent was used it or the stimulated lymphocytes and macrophages had to be carried to the neoplasm by the blood stream. Because of the relative ischaemia of most tumours, the agent or cells could therefore be brought into effective contact with only isolated or small agglomerations of tumour cells. It was thus mandatory that the main mass of tumour should be removed at operation and then the immunostimu-

\footnotetext{
* Surgeons in the cardiothoracic surgical unit at Broadgreen Hospital taking part in this trial were: B John Bickford, F Ronald Edwards, Ian M Morrison, Leslie J Temple, and J Kenneth B Waddington. Pathologists taking part were: F Whitwell, Broadgreen Hospital, Liverpool, W H Taylor, Fazakerley Hospital, Liverpool, and T Alban Lloyd, Royal Alexandra Hospital, Rhyl.

†This investigation has been supported by the Liverpool Cancer Research Committee, and we are grateful to the Liverpool Regional Cancer Organisation for the use of their clinical registry.
}

lant agent should be administered to control the growth of isolated non-demonstrable metastases, which would probably have been ultimately responsible for death. In view of the active cellular content of lymph nodes it might be that after operation small deposits left behind in these locations could be more adequately dealt with by the body after the use of an immunostimulant agent.

Of the materials available, BCG seemed to be the most acceptable as a supplement to the surgical resection of carcinoma of the lung. BCG could be given in one dose, and its action could persist for three to four months. It was unlikely to produce any serious side effects, and if it did these could be controlled by isoniazid (INAH).

\section{Method of administration of BCG}

It was considered that the standard technique of BCG inoculation by intradermal puncture or scarification could not be used satisfactorily in these rather elderly postoperative patients as it would require weekly or fortnightly visits, often from a distance. Accordingly, it was decided to give $0.5 \mathrm{ml}$ of BCG (Glaxo) $\left(5 \times 10^{6}\right.$ organisms) subdermally in the deltoid region 10 days after operation. This resulted in an active lesion presenting as a subcutaneous swelling $2-3 \mathrm{~cm}$ in diameter, 
which nearly always broke down into a series of sinuses or an ulcer $1-2 \mathrm{~cm}$ across. This type of reaction was relatively painless and required only a dry dressing that could be managed by the patient's family. Healing would not take place for four to six months. In only one case did a flagrant and spreading lesion develop and this was controlled by INAH. In a few secondary infection occurred, which was treated by an oral antibiotic.

\section{Establishment of the trial}

To discover the possible effects of giving BCG in the postoperative stages a pilot study was made of 60 consecutive surviving patients who had undergone lung resection by one surgeon between October 1970 and December 1971 and had been given BCG by the method described. The survival rate was compared with the previous 60 consecutive surviving patients, operated on by the same surgeon, who had not received BCG. Two-year and five-year follow-up reports of this series have been published (Edwards and Whitwell, 1974, 1978). As no serious complication followed the use of this technique, it was considered safe and a larger fully randomised trial was started in December 1971. It was considered that only a large number of cases of resection of lung carcinoma could eliminate those factors that influence small series. In view of the difficulties of assessing and analysing signs and symptoms in the months after operation, the only feature that would give a factual estimate of the effects of BCG would be the length of survival after operation. The determination of the survival rate at two years and five years after operation in the BCG and the control group was the purpose of this trial.

It was not possible to determine the exact cause of death in such a large group of cases, and the death certificate could not be accepted as a reliable explanation of the death of the patient. While most patients would die as a direct result of the extension of the malignant disease, quite a number would die of unrelated causes in view of the age of the group. It was assumed that in 500 cases the number would be similar in both groups.

Five hundred consecutive patients who survived resection of a carcinoma of the lung and who were discharged from hospital were selected for this trial. They were all operated on by members of the surgical staff of the Liverpool Regional Cardiothoracic Surgical Centre. The selection of cases for operation and the operative and postoperative management were similar for all surgeons. It is an agreed policy to undertake resection of the lung for carcinoma only if all macroscopic disease can be extirpated. The presence of affected lympl몬 nodes is not considered a contraindication to re $\overrightarrow{\widetilde{T}}$ section provided they can be removed. A patien with an oat cell carcinoma diagnosed by broncho⿰ scopic biopsy or sputum cytology was not con: sidered unsuitable for surgery, and was given $\dot{a}-$ preoperative assessment similar to patients with $\vec{w}$ other histological types. "Palliative" resection in the presence of irremovable extension of the tu $\vec{*}$ mour or distant metastases is undertaken only in the most exceptional circumstances, and any suctios cases were not entered into the trial.

Two hundred and fifty patients were to receive BCG in the postoperative phase, and 250 patients were used as a control. The choice of the group in which the patient was to be entered was based onp alternation by a disinterested person at the time of registration, which was three days after the oper $\frac{3}{0}$ ation. In the event 561 patients were registered, of whom 61 were rejected because of death before leaving hospital, change of diagnosis, or non-v administration of BCG.

The BCG was given on the tenth day after theo operation, and the patient then attended the routine follow-up in the outpatient department Adjuvant radiotherapy or chemotherapy was given to those patients who developed a late metastatic lesion causing symptoms.

Any patient who did not leave hospital after operation was rejected from the trial as the cause of death was probably related to the operation: rather than the carcinoma.

All resected specimens were submitted to one of three pathologists, and the histological reports used in the trial were those on the resected speci-3. men and the associated lymph nodes.

All patients were registered with the Mersey Regional Cancer Registry who undertake an annual follow-up of all cancer cases. The survival? of patients at two years was obtained with the helpo of this organisation. Five patients were untraceable, two in the control group and three in the $N$ BCG group, and these patients were assumed to N be dead.

\section{Results}

Table 1

Table 1 shows that the two groups were closely matched as to sex, type of operation, and histological type.

Table 2

The overall survival rate at two years was $114 / 250$ 
Table 1 Comparison of control and BCG groups

\begin{tabular}{|c|c|c|c|c|c|c|}
\hline \multirow[b]{2}{*}{$\begin{array}{l}\text { No of patients } \\
\text { Men } \\
\text { Women }\end{array}$} & \multicolumn{3}{|c|}{ Control } & \multicolumn{3}{|c|}{$B C G$} \\
\hline & $\begin{array}{r}250 \\
204 \\
46\end{array}$ & $\begin{array}{l}\text { Average age } \\
60 \cdot 1 \\
60 \cdot 4\end{array}$ & & $\begin{array}{r}250 \\
206 \\
44\end{array}$ & $\begin{array}{l}\text { Ave } \\
60 \cdot( \\
56 \cdot\end{array}$ & \\
\hline $\begin{array}{l}\text { Operations } \\
\text { Pneumonectomy } \\
\text { Lobectomy, bilobectomy, or sublobectomy }\end{array}$ & & & & & & \\
\hline $\begin{array}{l}\text { Histology } \\
\text { Squamous cell } \\
\text { Adenocarcinoma } \\
\text { Oat cell carcinoma } \\
\text { Carcinoma simplex } \\
\text { Mixed cell } \\
\text { Alveolar cell } \\
\text { Clear cell }\end{array}$ & $\begin{array}{r}152 \\
51 \\
15 \\
21 \\
5 \\
4 \\
2\end{array}$ & $\begin{array}{r}M \\
132 \\
40 \\
9 \\
15 \\
3 \\
3 \\
2\end{array}$ & $\begin{array}{r}\text { F } \\
20 \\
11 \\
6 \\
6 \\
2 \\
1 \\
0\end{array}$ & $\begin{array}{r}152 \\
47 \\
20 \\
23 \\
4 \\
1 \\
3\end{array}$ & $\begin{array}{r}\mathbf{M} \\
131 \\
39 \\
13 \\
17 \\
4 \\
0 \\
2\end{array}$ & $\begin{array}{r}\mathbf{F} \\
21 \\
8 \\
7 \\
6 \\
0 \\
1 \\
1\end{array}$ \\
\hline
\end{tabular}

Table 2 Two-year survival rate of histological types in control and BCG groups

\begin{tabular}{|c|c|c|c|c|c|c|}
\hline & \multicolumn{3}{|l|}{ Control } & \multicolumn{3}{|l|}{$B C G$} \\
\hline & Total No & Survivors & $\%$ & Total No & Survivors & $\%$ \\
\hline $\begin{array}{l}\text { Squamous cell } \\
\text { Adenocarcinoma } \\
\text { Oat cell carcinoma } \\
\text { Carcinoma simplex } \\
\text { Mixed cell carcinoma } \\
\text { Alveolar cell carcinoma } \\
\text { Clear cell carcinoma }\end{array}$ & $\begin{array}{r}152 \\
51 \\
15 \\
21 \\
5 \\
4 \\
2\end{array}$ & $\begin{array}{r}83 \\
15 \\
4 \\
8 \\
1 \\
1 \\
2\end{array}$ & $\begin{array}{l}54 \cdot 6 \\
29 \cdot 4 \\
26 \cdot 7 \\
38 \cdot 1 \\
20 \cdot 0 \\
25 \cdot 0 \\
100\end{array}$ & $\begin{array}{r}152 \\
47 \\
20 \\
23 \\
4 \\
1 \\
3\end{array}$ & $\begin{array}{r}77 \\
20 \\
6 \\
14 \\
1 \\
1 \\
0\end{array}$ & $\begin{array}{l}50 \cdot 6 \\
42 \cdot 6 \\
30 \cdot 0 \\
60 \cdot 9 \\
25 \cdot 0 \\
100 \\
0\end{array}$ \\
\hline Total & 250 & 114 & $45 \cdot 6 \%$ & 250 & 119 & $47 \cdot 6$ \\
\hline
\end{tabular}

$(45 \cdot 6 \%)$ in the control group and $119 / 250(47 \cdot 6 \%)$ for the BCG group.

\section{Table 3}

Comparing the two-year survival rate in the two sexes the number of male survivors was about the same in the two groups-(control $46.1 \%$; BCG $45 \cdot 6 \%$ ). There were however more female survivors in the BCG group (control $43.5 \%$; BCG $\left.56 \cdot 8 \% \cdot \chi^{2}=1 \cdot 6\right)$.

\section{Table 4}

Positive lymph nodes were found in 109 of the control group and 108 of the BCG group (table 4).
In the control group $26.6 \%$ of those with positive nodes and $60.3 \%$ of those with negative nodes survived two years, while in the BCG group $34.5 \%$ of those with positive nodes and $57.7 \%$ of those with negative nodes survived two years $\left(\chi^{2}=1 \cdot 5\right)$.

\section{Table 5}

Analysis of the sex distribution of the two-year survival of the positive and negative node groups shows that while the male survival rates were similar, there was a contrast, which however was not significant, in the survival rate of the women with positive nodes when comparing the two groups:

Table 3 Two-year survival rate in men and women in control and BCG groups

\begin{tabular}{|c|c|c|c|c|c|c|c|c|c|c|}
\hline & \multicolumn{5}{|c|}{ Control } & \multicolumn{5}{|l|}{$B C G$} \\
\hline & \multirow{2}{*}{$\frac{\text { Total }}{\text { No }}$} & \multicolumn{2}{|c|}{ Male survivors } & \multicolumn{2}{|c|}{ Female survivors } & \multirow{2}{*}{$\frac{\text { Total }}{\text { No }}$} & \multicolumn{2}{|c|}{ Male survivors } & \multicolumn{2}{|c|}{ Female survivors } \\
\hline & & No & $\%$ & No & $\%$ & & No & $\%$ & No & $\%$ \\
\hline $\begin{array}{l}\text { Squamous cell } \\
\text { Adenocarcinoma } \\
\text { Oat cell carcinoma } \\
\text { Carcinoma simplex } \\
\text { Mixed cell } \\
\text { Alveolar cell } \\
\text { Clear cell }\end{array}$ & $\begin{array}{r}152 \\
51 \\
15 \\
21 \\
5 \\
4 \\
2\end{array}$ & $\begin{array}{l}73 / 132 \\
11 / 40 \\
2 / 9 \\
5 / 15 \\
1 / 3 \\
0 / 3 \\
2 / 2\end{array}$ & $\begin{array}{c}55 \cdot 3 \\
27 \cdot 5 \\
22 \cdot 2 \\
33 \cdot 3 \\
33 \cdot 3 \\
0 \cdot 0 \\
100\end{array}$ & $\begin{array}{c}10 / 20 \\
4 / 11 \\
2 / 6 \\
3 / 6 \\
0 / 2 \\
1 / 1 \\
0 / 0\end{array}$ & $\begin{array}{c}50 \cdot 0 \\
36 \cdot 4 \\
33 \cdot 3 \\
50 \cdot 0 \\
0 \cdot 0 \\
100 \\
-\end{array}$ & $\begin{array}{r}152 \\
47 \\
20 \\
23 \\
4 \\
1 \\
3\end{array}$ & $\begin{array}{c}66 / 131 \\
15 / 39 \\
3 / 13 \\
9 / 17 \\
1 / 4 \\
0 / 0 \\
0 / 2\end{array}$ & $\begin{array}{l}50 \cdot 4 \\
38 \cdot 5 \\
23 \cdot 1 \\
52 \cdot 9 \\
25 \cdot 0 \\
-0 / 0\end{array}$ & $\begin{array}{c}11 / 21 \\
5 / 8 \\
3 / 7 \\
5 / 6 \\
0 / 0 \\
1 / 1 \\
0 / 1\end{array}$ & $\begin{array}{c}52 \cdot 4 \\
62 \cdot 5 \\
42 \cdot 8 \\
83 \cdot 3 \\
- \\
100 \\
0 \cdot 0\end{array}$ \\
\hline Total & 250 & $94 / 204$ & $46 \cdot 1$ & $20 / 46$ & $46 \cdot 1$ & 250 & $94 / 206$ & $45 \cdot 6$ & $25 / 44$ & $56 \cdot 8$ \\
\hline
\end{tabular}


Table 4 Two-year survival rate of patients with positive and negative nodes in different histological groups

\begin{tabular}{|c|c|c|c|c|c|c|c|c|c|c|c|c|}
\hline & \multicolumn{6}{|c|}{ Control } & \multicolumn{6}{|l|}{$B C G$} \\
\hline & \multicolumn{3}{|c|}{ Nodes positive } & \multicolumn{3}{|c|}{ Nodes negative } & \multicolumn{3}{|c|}{ Nodes positive } & \multicolumn{3}{|c|}{ Nodes negative } \\
\hline & \multirow[t]{2}{*}{ Total } & \multicolumn{2}{|c|}{ Alive } & \multirow[t]{2}{*}{ Total } & \multicolumn{2}{|c|}{ Alive } & \multirow[t]{2}{*}{ Total } & \multicolumn{2}{|c|}{ Alive } & \multirow[t]{2}{*}{ Total } & \multicolumn{2}{|c|}{ Alive } \\
\hline & & No & $\%$ & & No & $\%$ & & $N o$ & $\%$ & & No & $\%$ \\
\hline $\begin{array}{l}\text { Squamous cell } \\
\text { Adenocarcinoma } \\
\text { Oat cell carcinoma } \\
\text { Carcinoma simplex } \\
\text { Mixed cell } \\
\text { Alveolar cell } \\
\text { Clear cell }\end{array}$ & $\begin{array}{r}67 \\
24 \\
9 \\
6 \\
1 \\
2 \\
0\end{array}$ & $\begin{array}{r}25 \\
2 \\
1 \\
1 \\
0 \\
0 \\
0\end{array}$ & $\begin{array}{r}37 \cdot 3 \\
8 \cdot 3 \\
11 \cdot 1 \\
16 \cdot 7 \\
0 \cdot 0 \\
0 \cdot 0 \\
0 \cdot 0\end{array}$ & $\begin{array}{r}85 \\
27 \\
6 \\
15 \\
4 \\
2 \\
2\end{array}$ & $\begin{array}{r}58 \\
13 \\
3 \\
7 \\
1 \\
1 \\
2\end{array}$ & $\begin{array}{r}68 \cdot 2 \\
48 \cdot 1 \\
50 \cdot 0 \\
46 \cdot 7 \\
25 \cdot 0 \\
50 \cdot 0 \\
100 \cdot 0\end{array}$ & $\begin{array}{r}62 \\
23 \\
12 \\
8 \\
3 \\
0 \\
0\end{array}$ & $\begin{array}{r}25 \\
6 \\
2 \\
3 \\
1 \\
0 \\
0\end{array}$ & $\begin{array}{r}40 \cdot 3 \\
26 \cdot 1 \\
16 \cdot 7 \\
37 \cdot 5 \\
33 \cdot 3 \\
0 \cdot 0 \\
0 \cdot 0\end{array}$ & $\begin{array}{r}90 \\
24 \\
8 \\
15 \\
1 \\
1 \\
3\end{array}$ & $\begin{array}{r}52 \\
14 \\
4 \\
11 \\
0 \\
1 \\
0\end{array}$ & $\begin{array}{r}57 \cdot 8 \\
58 \cdot 4 \\
50 \cdot 0 \\
73 \cdot 3 \\
0 \cdot 0 \\
100 \cdot 0 \\
0 \cdot 0\end{array}$ \\
\hline Total & 109 & 29 & $26 \cdot 6$ & 141 & 85 & $60 \cdot 8$ & 108 & 37 & $34 \cdot 3$ & 142 & 82 & $57 \cdot 7$ \\
\hline
\end{tabular}

Table 5 Two-year survival rate of men and women with positive and negative nodes

\begin{tabular}{|c|c|c|c|c|c|c|c|c|c|c|c|c|c|c|c|c|}
\hline & \multicolumn{8}{|c|}{ Control } & \multicolumn{8}{|l|}{$B C G$} \\
\hline & \multicolumn{4}{|c|}{ Nodes positive } & \multicolumn{4}{|c|}{ Nodes negative } & \multicolumn{4}{|c|}{ Nodes positive } & \multicolumn{4}{|c|}{ Nodes negative } \\
\hline & $\begin{array}{l}\text { Men } \\
\text { alive }\end{array}$ & $\%$ & $\begin{array}{l}\text { Women } \\
\text { alive }\end{array}$ & en & $\begin{array}{l}\text { Men } \\
\text { alive }\end{array}$ & $\%$ & $\begin{array}{l}\text { Women } \\
\text { alive }\end{array}$ & \% & $\begin{array}{l}\text { Men } \\
\text { alive }\end{array}$ & $\%$ & $\begin{array}{l}\text { Women } \\
\text { alive }\end{array}$ & ? & $\begin{array}{l}\text { Men } \\
\text { alive }\end{array}$ & $\%$ & $\begin{array}{l}\text { Women } \\
\text { alive }\end{array}$ & $n^{n} \%$ \\
\hline $\begin{array}{l}\text { Squamous cell } \\
\text { Adenocarcinoma } \\
\text { Oat cell carcinoma } \\
\text { Carcinoma }\end{array}$ & $\begin{array}{l}23 / 58 \\
1 / 17 \\
0 / 6\end{array}$ & $\begin{array}{r}39.7 \\
5.9 \\
0.0\end{array}$ & $\begin{array}{l}2 / 9 \\
1 / 7 \\
1 / 3\end{array}$ & $\begin{array}{l}22 \cdot 2 \\
14 \cdot 3 \\
33 \cdot 3\end{array}$ & $\begin{array}{c}50 / 74 \\
10 / 23 \\
2 / 3\end{array}$ & $\begin{array}{c}65 \cdot 5 \\
43 \cdot 5 \\
66 \cdot 6\end{array}$ & $\begin{array}{l}8 / 11 \\
3 / 4 \\
1 / 3\end{array}$ & $\begin{array}{r}72 \cdot 7 \\
75 \cdot 0 \\
33 \cdot 3\end{array}$ & $\begin{array}{c}20 / 50 \\
3 / 19 \\
2 / 9\end{array}$ & $\begin{array}{l}40.0 \\
15 \cdot 8 \\
22.2\end{array}$ & $\begin{array}{l}5 / 12 \\
3 / 4 \\
0 / 3\end{array}$ & $\begin{array}{r}41 \cdot 7 \\
75 \cdot 0 \\
0.0\end{array}$ & $\begin{array}{c}46 / 81 \\
12 / 20 \\
1 / 4\end{array}$ & $\begin{array}{l}56 \cdot 8 \\
60 \cdot 0 \\
25 \cdot 0\end{array}$ & $\begin{array}{l}6 / 9 \\
2 / 4 \\
3 / 4\end{array}$ & $\begin{array}{l}66 \cdot 7 \\
50 \cdot 0 \\
75 \cdot 0\end{array}$ \\
\hline $\begin{array}{l}\text { simplex } \\
\text { Mixed cell } \\
\text { Alveolar cell } \\
\text { Clear cell }\end{array}$ & $\begin{array}{l}1 / 5 \\
0 / 0 \\
0 / 2 \\
0 / 0\end{array}$ & $\begin{array}{r}20 \cdot 0 \\
0.0 \\
0 \cdot 0 \\
0.0\end{array}$ & $\begin{array}{l}0 / 1 \\
0 / 1 \\
0 / 0 \\
0 / 0\end{array}$ & $\begin{array}{l}0.0 \\
0.0 \\
0.0 \\
0.0\end{array}$ & $\begin{array}{l}4 / 10 \\
1 / 3 \\
0 / 1 \\
2 / 2\end{array}$ & $\begin{array}{r}40 \cdot 0 \\
33 \cdot 3 \\
0 \cdot 0 \\
100 \cdot 0\end{array}$ & $\begin{array}{l}3 / 5 \\
0 / 1 \\
1 / 1 \\
0 / 0\end{array}$ & $\begin{array}{r}60 \cdot 0 \\
0 \cdot 0 \\
100 \cdot 0 \\
100 \cdot 0\end{array}$ & $\begin{array}{l}1 / 6 \\
1 / 3 \\
0 / 0 \\
0 / 0\end{array}$ & $\begin{array}{r}16 \cdot 6 \\
33 \cdot 3 \\
0 / 0 \\
0 / 0\end{array}$ & $\begin{array}{l}2 / 2 \\
0 / 0 \\
0 / 0 \\
0 / 0\end{array}$ & $\begin{array}{r}100.0 \\
0.0 \\
0.0 \\
0.0\end{array}$ & $\begin{array}{l}8 / 11 \\
0 / 1 \\
0 / 0 \\
0 / 2\end{array}$ & $\begin{array}{r}72 \cdot 7 \\
0 \cdot 0 \\
0 \cdot 0 \\
0 \cdot 0\end{array}$ & $\begin{array}{l}3 / 4 \\
0 / 0 \\
1 / 1 \\
0 / 1\end{array}$ & $\begin{array}{r}75 \cdot 0 \\
0 \cdot 0 \\
100 \cdot 0 \\
0.0\end{array}$ \\
\hline Total & $25 / 88$ & $28 \cdot 4$ & $4 / 21$ & $19 \cdot 0$ & $69 / 116$ & $59 \cdot 5$ & $16 / 25$ & $64 \cdot 0$ & $27 / 87$ & $31 \cdot 0$ & $10 / 21$ & $47 \cdot 6$ & $67 / 119$ & $56 \cdot 3$ & $15 / 23$ & $65 \cdot 2$ \\
\hline
\end{tabular}

$\frac{\text { Female positive nodes control }}{\text { Female positive nodes BCG }}=\frac{4 / 21}{10 / 21}=\frac{19 \cdot 0 \%}{47 \cdot 6 \%}$ $\left(\chi^{2}=3.86\right.$ with Yates's correction $\left.\chi^{2}=2 \cdot 68\right)$. $(\mathrm{P}=0 \cdot 10)$.

Table 6 Survival in the main histological types of lung carcinoma

While no results based on survival can be fully accepted until a five-year survey is carried out, certain observations on the possible effect of BCG on the various histological types can be made as a result of the two-year survey.
Squamous cell carcinoma-In this differentiated group the total number of survivors who had received BCG $(77 / 152=50.6 \%)$ was less than theo controls $(83 / 152=54 \cdot 6 \%)$. The number of women with positive nodes alive at two years was nearlyo twice as many in the BCG treated cases $(5 / 12=3$. $41 \cdot 7 \%)$ as in the controls $(2 / 9=22 \cdot 2 \%)$.

Adenocarcinoma-The total survival rate in the BCG group was higher $(20 / 47=42.6 \%)$ than ino the controls $(15 / 51=29 \cdot 4 \%) \chi^{2}=1 \cdot 84$. All groups except women with negative nodes show more sur을 vivors when given $\mathrm{BCG}$.

Table 6 Composite table of two-year survival of main histological groups

\begin{tabular}{|c|c|c|c|c|c|c|c|c|}
\hline & \multicolumn{2}{|c|}{ Squamous cell carcinoma } & \multicolumn{2}{|c|}{ Adenocarcinoma } & \multicolumn{2}{|c|}{ Oat cell carcinoma } & \multicolumn{2}{|c|}{ Carcinoma simplex } \\
\hline & Control & $B C G$ & Control & $B C G$ & Control & $B C G$ & Control & $B C G$ \\
\hline No of patients & 152 & 152 & 51 & 47 & 15 & 20 & 21 & 23 \\
\hline $\begin{array}{l}\text { Men: Total } \\
\text { With positive nodes } \\
\text { With negative nodes }\end{array}$ & $\begin{array}{l}\text { Percenta } \\
55 \cdot 3 \\
39 \cdot 7 \\
65 \cdot 5\end{array}$ & $\begin{array}{c}\text { wo-year surv } \\
50 \cdot 4 \\
40 \cdot 0 \\
56.8\end{array}$ & $\begin{array}{l}\text { vival rate } \\
27 \cdot 5 \\
5 \cdot 9 \\
43 \cdot 5\end{array}$ & $\begin{array}{l}38 \cdot 5 \\
15 \cdot 8 \\
60 \cdot 0\end{array}$ & $\begin{array}{r}22 \cdot 2 \\
0 \cdot 0 \\
66 \cdot 6\end{array}$ & $\begin{array}{l}23 \cdot 1 \\
22 \cdot 2 \\
25 \cdot 0\end{array}$ & $\begin{array}{l}33 \cdot 3 \\
20 \cdot 0 \\
40 \cdot 0\end{array}$ & $\begin{array}{l}52 \cdot 9 \\
16 \cdot 6 \\
72 \cdot 7\end{array}$ \\
\hline $\begin{array}{l}\text { Women: Total } \\
\text { With positive nodes } \\
\text { With negative nodes }\end{array}$ & $\begin{array}{l}50 \cdot 0 \\
22 \cdot 2 \\
72 \cdot 7\end{array}$ & $\begin{array}{l}52 \cdot 4 \\
41 \cdot 7 \\
66 \cdot 7\end{array}$ & $\begin{array}{l}36 \cdot 4 \\
14 \cdot 3 \\
75 \cdot 0\end{array}$ & $\begin{array}{l}62 \cdot 5 \\
75 \cdot 0 \\
50 \cdot 0\end{array}$ & $\begin{array}{l}33 \cdot 3 \\
33 \cdot 3 \\
33 \cdot 3\end{array}$ & $\begin{array}{r}42 \cdot 8 \\
0 \cdot 0 \\
75 \cdot 0\end{array}$ & $\begin{array}{r}50 \cdot 0 \\
0 \cdot 0 \\
60 \cdot 0\end{array}$ & $\begin{array}{r}83 \cdot 3 \\
100 \cdot 0 \\
75 \cdot 0\end{array}$ \\
\hline Total & $54 \cdot 6$ & $50 \cdot 6$ & $29 \cdot 4$ & $42 \cdot 6$ & $26 \cdot 7$ & $30 \cdot 0$ & $38 \cdot 1$ & 60.9 \\
\hline
\end{tabular}


Oat cell carcinoma (small cell carcinoma)The two-year survival rate in all categories of patients with an oat cell carcinoma are similar whether BCG was given or not. It might be expected that in this active form of tumour the speed of cell multiplication would be much greater than could be coped with by cellular immunity, however much it was stimulated. It should be noted, however, that over a quarter of the patients in both groups survived two years (control group $4 / 15=26 \cdot 7 \%$, BCG group $6 / 20=30 \cdot 0 \%$ ). While these results are not good they do not justify the pessimism concerning surgery for oat cell carcinoma that has recently developed.

Carcinoma simplex (undifferentiated carcinoma) -The survival rate at two years of the BCG group is considerably better than that of the controls.

$\frac{\text { Carcinoma simplex controls }}{\text { Carcinoma simplex BCG }}=\frac{8 / 21}{14 / 23}=\frac{38 \cdot 1 \%}{60 \cdot 9 \%}$
$\chi^{2}=2 \cdot 3$; with Yates's correction $\chi^{2}=1 \cdot 1$.

This improved survival rate with BCG is reflected throughout all categories of the carcinoma simplex group, and the undifferentiated cell may be more susceptible to cellular immunity.

Mixed cell carcinoma, alveolar cell carcinoma (bronchiolar carcinoma, pulmonary adenomatosis), and clear cell carcinoma-The numbers in these three groups are too small for any discussion.

Although there are trends visible in the response of these different histological types to the administration of BCG, none of the figures are statistically significant. Similar trends were noticeable in our original pilot study at the two-year review, but they became less definite at five years (Edwards and Whitwell, 1974, 1978).

\section{Table 7 Length of survival of patients dying at} two years

There is a slightly longer average survival (six weeks) in the patients dying under two years who had received BCG. This was more noticeable in the squamous cell group (nine weeks) (table 8).

Table 7 Length of survival in months of patients dying in under two years after lung resection

\begin{tabular}{lll}
\hline & Control & BCG \\
\hline No of patients & 136 & 131 \\
& Months & \\
Men & $8 \cdot 8$ & $10 \cdot 3$ \\
Women & $9 \cdot 4$ & $11 \cdot 1$ \\
Total & 8.9 & $10 \cdot 4$ \\
\hline
\end{tabular}

Table 8 Length of survival in months of patients dying in under two years after lung resectionhistological groups

\begin{tabular}{|c|c|c|c|c|}
\hline & \multicolumn{2}{|l|}{ Control } & \multicolumn{2}{|l|}{$B C G$} \\
\hline & $\begin{array}{l}\text { No of } \\
\text { patients }\end{array}$ & Months & $\begin{array}{l}\text { No of } \\
\text { patients }\end{array}$ & Months \\
\hline $\begin{array}{l}\text { Squamous cell carcinoma } \\
\text { Adenocarcinoma } \\
\text { Oat cell carcinoma } \\
\text { Carcinoma simplex } \\
\text { Others }\end{array}$ & $\begin{array}{r}69 \\
36 \\
11 \\
13 \\
7\end{array}$ & $\begin{array}{r}8 \cdot 8 \\
8 \cdot 9 \\
7 \cdot 4 \\
10 \cdot 4 \\
9 \cdot 9\end{array}$ & $\begin{array}{r}75 \\
27 \\
14 \\
9 \\
6\end{array}$ & $\begin{array}{r}11 \cdot 0 \\
10 \cdot 6 \\
7 \cdot 1 \\
10 \cdot 3 \\
10 \cdot 4\end{array}$ \\
\hline Total & 136 & $8 \cdot 9$ & 131 & $10 \cdot 4$ \\
\hline
\end{tabular}

\section{TYPE OF OPERATION}

It was decided that a detailed analysis as to whether survival was affected by the type of operation would be of no value. The age and size of a tumour influences the surgeon in deciding whether a pneumonectomy or a lesser operation is required; similarly, the presence of hilar glands, even though the primary tumour was small, would encourage a more radical type of operation.

\section{Conclusions}

After resection for lung carcinoma the administration of BCG has resulted in a numerically improved survival rate in adenocarcinoma $(29.4 \%$ to $42.6 \%)$ and carcinoma simplex $(38.1 \%$ to $60.9 \%$ ). The survival rate in women as a whole is improved $(46.1 \%$ to $56.8 \%)$. There is a small increase in the survival of those with positive nodes at the time of operation $(26.6 \%$ to $34.3 \%)$, but this is mainly due to a striking increase in the female survivors in this group $(19.0 \%$ to $47 \cdot 6 \%)$.

Patients dying within two years of operation have lived on average 1.5 months longer with BCG (8.9 to 10.4 months).

None of the above figures is statistically significant. The impression is gained, however, throughout this survey that BCG has a more specific action on women than men. Whether it is easier to stimulate the immune system in women, or whether there is some other factor is not clear. Further study of this aspect might be profitable.

I thank Professor David Price-Evans for his help and advice with the statistics.

\section{References}

Biozzi, G, Halpern, B N, Bilbey, D, Stiffel, C, Benacerraf, B, and Mouton, D (1957). Oestrogen and the phagocytic function of the reticuloendothelial system. Comptes Rendus de la Sociéte de Biologie (Paris), 151, 1326-1331. 
Bradner, W T, Clarke, D A, and Stock, C C (1958). Stimulation of host defences against experimental cancer. I. Zymosan and S-180 in mice. Cancer Research, 18, 347-351.

Edwards, F R, and Whitwell, F (1974). Use of BCG as an immunostimulant in the surgical treatment of carcinoma of the lung. Thorax, 29, 654-658.

Edwards, F R, and Whitwell, F (1978). Use of BCG as an immunostimulant in the surgical treatment of carcinoma of the lung; a five-year follow-up report. Thorax, 33, 250-252.

Halpern, B N, Biozzi, G, Stiffel, C, and Mouton, D (1966). Inhibition of tumour growth by the admin- istration of killed Corynebacterium parvum. Nature. 212, 853-854.

Old, L J, Clarke, D A, and Benacerraf, B (1959). Effect of Bacillus Calmette-Guèrin infection on $\widetilde{\Phi}$ transplanted tumours in the mouse. Nature, 184, 291-292.

Oppenheim, J J, Wang, J, and Frei, E (1965). Im- $\vec{\circ}$ munologic and cytogenic studies of chronic lymphatic leukaemic cells. Blood, 26, 121.

Requests for reprints to: Mr F R Edwards, Cardio- $\frac{\overrightarrow{\vec{x}}}{\times}$ thoracic Surgical Unit, Broadgreen Hospital, Liver- $\dot{\omega}$ pool L14 3LB. 